\title{
Accounting Consistency in Kaleckian Models of Growth and Distribution: a Preliminary Step and a Research Agenda
}

Consistência Contábil em Modelos Kaleckianos de Crescimento e Distribuição: um Passo Preliminar e uma Agenda de Pesquisa

\author{
Sylvio Antonio Kappes ${ }^{\mathrm{a}}$ \\ Henrique Morrone ${ }^{b}$
}

\begin{abstract}
Resumo: Crescimento econômico e distribuição de renda são assuntos debatidos na literatura, tanto nas tradições mainstream quanto heterodoxa. Outra preocupação são as crises financeiras. Pós-Keynesianos lidaram com o primeiro tópico empregando modelos kaleckianos de crescimento e distribuição de renda, e com o segundo via modelos de estoques e fluxos. O objetivo deste artigo é integrar as abordagens através de balanços financeiros macroeconômicos. Após essas estimações, construímos um modelo e aplicamos aos dados de países da OCDE. Nossos resultados ressaltam a capacidade do modelo de explicar alguns puzzles na literatura Kaleckiana. Por fim, apresentamos uma agenda de pesquisa.
\end{abstract}

Palavras-chave: Modelos de Consistência entre Estoques e Fluxos; Crescimento Econômico; Distribuição de Renda..

Classificação JEL: B00, D33, E13.

\begin{abstract}
Economic growth and income distribution are hotly debated topics in economics, both in mainstream and heterodox traditions. Another concern in economic literature centers on financial crisis. Some Post-Keynesians have tackled the first theme by employing Kaleckian models, and the second through Stock-Flow Consistent Models. This paper integrates both approaches by means of macroeconomic financial balances. After estimating these balances, we build a theoretical model and apply it to some OECD countries' dataset. Our findings underscore the model's capacity to explain some puzzles in the Kaleckian literature. Finally, we present a research agenda in order to improve our model.
\end{abstract}

Keywords: Stock-Flow Consistent Models; Economic Growth; Income Distribution.

a Doutorando em economia do desenvolvimento pela Universidade Federal do Rio Grande do Sul (UFRGS). E-mail: sylviokappes@gmail.com.

b Professor da Universidade Federal do Rio Grande do Sul (UFRGS). E-mail: hmorrone@ hotmail.com. 


\section{Introduction}

Economic growth and income distribution are key topics in mainstream and heterodox traditions. In the first group, the main concerns about secular stagnation (SUMMERS, 2014; EGGERTSSON ET AL., 2016. GORDON, 2016) and the increase in inequality at the global scale (PIKETTY, 2014). In the second group, there is a long tradition of theories that analyze the effects of income distribution on growth.

Another concern in economic literature centers on financial crisis. In the mainstream approach, there is a growing effort to introduce the financial side in DSGE models (BRUNNERMEIER ET AL., 2012). The heterodox approach emphasizes the consistent modeling of financial stocks and flows, in the well-known Stock Flow Consistent (SFC) models.

This paper, which follows the heterodox tradition, presents a theoretical model that integrates the accounting consistency of SFC models with Kaleckian models of growth and distribution. This model is used to analyze the evolution of macroeconomic financial balances of selected OECD countries, as well as the behavior of their demand and accumulation regimes. Moreover, we establish an agenda for future research.

The paper is organized as follows. In the next section, we explain the importance of the consistent modeling of stocks and flows and introduce the transactions flows matrix that will be used along the discussion. We explore data concerning macroeconomic financial balances in the third section. In the fourth section, an accounting consistent growth and distribution model is developed. The last section presents a research agenda and concludes.

\section{Accounting Consistency in Economic Models}

The concern about the consistent modeling of both stocks and flows has a relatively recent history in economic thought. Brainard and Tobin (1968), for example, is an early attempt to model the interrelations between the financial portfolios of the macroeconomic sectors in an IS-LM model. Godley and Cripps (1983) is the seminal work of an economic tradition known as New Cambridge ${ }^{1}$, whose models are based on accounting identities and stock-flow norms that drive the behavior of economic agents. More recently, the PostKeynesian school gave rise to the so-called Stock-Flow Consistent (SFC) models ${ }^{2}$.

Accounting consistency in economic models can be justified both on theoretical and empirical grounds. In the first, we pinpoint some arguments raised by SFC practitioners. Godley (1996, p. 7) points to the fact that, in those models, "[...] there are no black holes: every flow comes from somewhere and goes somewhere". Lavoie (2008, p.332-333) argues

\footnotetext{
${ }^{1}$ On this school, see Mata (2012).

${ }^{2}$ The seminal work on this tradition is Godley and Lavoie (2007). For surveys of this literature, see Caverzasi and Godin (2015) and Nikiforos and Zezza (2017).
} 
that "it provides a potential for common ground for all heterodox schools, just like the maximizing representative agent seems to be the standard of mainstream economics".

The introduction of accounting consistency has powerful theoretical consequences. For instance, Godley and Shaikh (2002) shows that the classical dichotomy between real and nominal variables that appears in standard neoclassical models no longer applies if stocks and flows are properly modeled. Taylor (2004) applies the idea to an IS-LM-BP model and shows that the dichotomy between fixed external reserves and floating exchange rate versus floating external reserves and fixed exchange rate disappears. As a final example, Richters and Siemoneit (2017), who criticize the notion that there is a growth imperative $^{3}$ in capitalist economies, point to accounting inconsistencies in several growth models.

On the empirical ground, an important argument is that accounting consistency is crucial in forecasting financial crisis. Bezemer (2010) shows that this feature appears in the analysis of the few economists who foresaw the 2008 subprime crisis. Moreover, it is possible to analyze the sustainability of economic trends and to detect inconsistencies in policy proposals, as it will be shown below.

In order to develop our argument, we present a transactions flow matrix, in Table 1, which considers three sectors: private, government and external. Each entry with a plus sign represents a source of funds to the corresponding sector, whereas a minus sign denotes a use of funds.

In the first row, Table 1 shows private consumption, whose entries are both inside the Private Sector current expenditures column. Below, there are government consumption and taxes, two transactions that involve private and government sectors. The next two rows compute imports and exports, which occur between the private and external sectors. Finally, Table 1 exhibits private investment and savings. Notice that the usual National Account identity, $Y=C+I+G+X-M$, is contained inside the private sector column. Savings are derived from its definition, $S=Y-T-C$.

The "column sub-total" represents the net lending or net borrowing positions of each sector. For example, if the government has a budget deficit, its sub-total has a negative sign. Since every row in the matrix must sum to zero, this result of the government must be compensated by the remaining sectors. This row can be represented as follows:

$$
(S-I)+(T-G)+(M-X)=0
$$

This equation reveals that, for example, a private sector surplus must be matched by government deficits and current account surpluses. This simple accounting relation provides insights about the working of economies and highlights potential flaws in theoretical models. This is the benchmark upon which we will construct our theoretical and empirical analysis in the next sections.

\footnotetext{
${ }^{3}$ In sum, this idea is that an economic system must grow in order to be stable, due to the existence of debt that must be repaid.
} 
Several authors have used equation (1) to assess the sustainability of economic trends. Wynne Godley's "seven unsustainable processes" (Godley, 1999) is perhaps the most famous one. He stated that the accumulation of flows from increasing private sector deficit, in conjunction with government surplus and external deficits, could trigger potentially disruptive adjustments. Kregel (2011) employed the equation to criticize the policy restrictions imposed on Greece after the sovereign crisis. Caldentey and Vernengo (2015) analyze the different responses of Central and South America to the subprime crisis, stressing the composition of sectoral balances of those regions and its economic consequences ${ }^{4}$.

Furthermore, equation (1) has also attracted theoretical attention. Both Vera (2009) and Ocampo et al. (2009) worked with this equation to criticize mainstream policy recommendations based on the Twin Deficits and Ricardian Equivalence theorems ${ }^{5}$.

Having discussed the importance of accounting consistency in economic models, we can turn to our empirical analysis and, then, to our theoretical model.

\section{Table 1: Transactions Matrix of an Open Economy with Government}

\begin{tabular}{|c|c|c|c|c|c|}
\hline & \multicolumn{2}{|c|}{ Private Sector } & \multirow{2}{*}{ Government Sector } & \multirow{2}{*}{ External Sector } & \multirow{2}{*}{ Total } \\
\hline & Current & Capital & & & \\
\hline Private consumption & $-\mathrm{C},+\mathrm{C}$ & & & & 0 \\
\hline Government consumption & $+\mathrm{G}$ & & $-G$ & & 0 \\
\hline Taxes & $-\mathrm{T}$ & & $+\mathrm{T}$ & & 0 \\
\hline Imports & $-\mathrm{M}$ & & & $+\mathrm{M}$ & 0 \\
\hline Exports & $+\mathrm{X}$ & & & $-X$ & 0 \\
\hline Investment & $+\mathrm{I}$ & $-\mathrm{I}$ & & & 0 \\
\hline Private sector savings & $-S$ & $+\mathrm{S}$ & & & 0 \\
\hline Column sub-total & \multicolumn{2}{|c|}{$(\mathrm{S}-\mathrm{I})$} & $(\mathrm{T}-\mathrm{G})$ & $(\mathrm{M}-\mathrm{X})$ & 0 \\
\hline Changes in Net Debt & \multicolumn{2}{|c|}{$\Delta \mathrm{D}_{\mathrm{p}}$} & $\Delta \mathrm{D}_{\mathrm{g}}$ & $\Delta \mathrm{D}_{\mathrm{f}}$ & 0 \\
\hline
\end{tabular}

Source: Authors' own elaboration, based on Dafermos (2017) and Vera (2009).

\footnotetext{
${ }^{4}$ For more on this approach, see also Eatwell and Taylor (1999), Godley and McCarthy (1998), Santos (2004), Santos (2017), Santos and Oreiro (2019), Godley and Izurieta (2004), Godley et al. (2007), Zezza (2009), Brecht et al. (2012) and Rezende (2016). For a review of Godley's strategic analysis, see Bibow (2012).

${ }^{5}$ Very briefly, the Twin Deficits hypothesis is that a government budget deficit expands domestic demand above a point that guarantees an external equilibrium, thus causing a current account deficit. The Ricardian Equivalence Theorem is that the private sector increases its savings in face of a government deficit, because they expect a raise in taxes in a future period. Note that both theories assume that some macroeconomic balance is in equilibrium: in the former, it is the private sector; in the latter, it is the external sector.
} 


\section{Sectoral Balances: an Overview and Empirical Analysis for some OECD Countries}

In this section, we present an empirical analysis of the sectoral balances discussed in the previous section. Before delving into the numbers, we start from the basic national income identity:

$$
G D P_{m p}=C+I_{p}+I_{g}+G+N X
$$

where $G D P_{m p}$ is Gross Domestic Product at market prices, $C$ is private final consumption, $I_{p}$ is private gross capital formation, $I_{g}$ is government gross capital formation, $G$ is government final expenditures and $N X$ is net exports.

Now, we add NPI*, Net Private Income of the external sector, to both sides of this identity, and subtract from both sides $T$, total taxes.

$$
G D P_{m p}+N P I^{*}-T=C+I_{p}+I_{g}+G+N X+N P I^{*}-T
$$

Lastly, we consider net transfers from one sector to another: $N T G_{p s}$ are net transfers of the government to the private sector; $N T G_{e x}$ are net transfers of the government to the external sector; and $N T P_{e x}$ are net transfers of the private sector to the external sector.

$$
\begin{aligned}
G D P_{m p}+N P I^{*}- & T+N T G_{p s}-N T G_{e x}-N T P_{e x} \\
= & C+I_{p}+I_{g}+G+N X+N P I^{*}-T+N T G_{p s}-N T G_{e x}-N T P_{e x}
\end{aligned}
$$

To develop our empirical analysis, OECD (2018) database was employed. There is no data on $N T G_{p s}$. $N T G_{e x}$ and $N T P_{e x}$ are comprised in a single heading, Net Current Transfers Receivable from Abroad $(N C T)$. $I_{p}$ is derived residually, by subtracting Gross Capital Formation of the Government from the Gross Capital Formation. Table A1, in the appendix, shows the correspondence of the above notation with data from OECD (2018), bringing also the national accounts codes.

Based on this data we can rewrite equation (4) as:

$$
G D P_{m p}+N C T+N P I-T=C+I_{p}+I_{g}+G+N X+N C T+N P I-T
$$

The left-hand side of the above equation is the private disposable income. If we subtract consumption, we get private savings. Note also that $N X+N C T+N P I$ is the Current Account balance. Rearranging those items, we get:

$$
\left(S-I_{p}\right)=\left(G+I_{g}-T\right)+C A
$$

The sectoral balances given by equation (6) assume a variety of behaviors in the data. In Figure 1(a), the time series of government and private balances in France move in tandem: when one of them grows, the other falls. Note also the downward trend of the external balance, moving from a surplus of about 3\% of GDP in 1997 to a deficit of $1 \%$ of GDP in 2016. Regarding short-term forecasts, we point to the increasing divergence between government and private balances, a divergence that has occurred before and has 
been corrected by means of decreasing government balance and increasing private balance. This should be accounted for in government budget proposals, for instance, since it is likely that this sector will experience a deterioration of its balance.

Figure 1: Sectoral Balances of OECD Countries: France (a), Estonia (b), Spain (c), and Hungary (d)

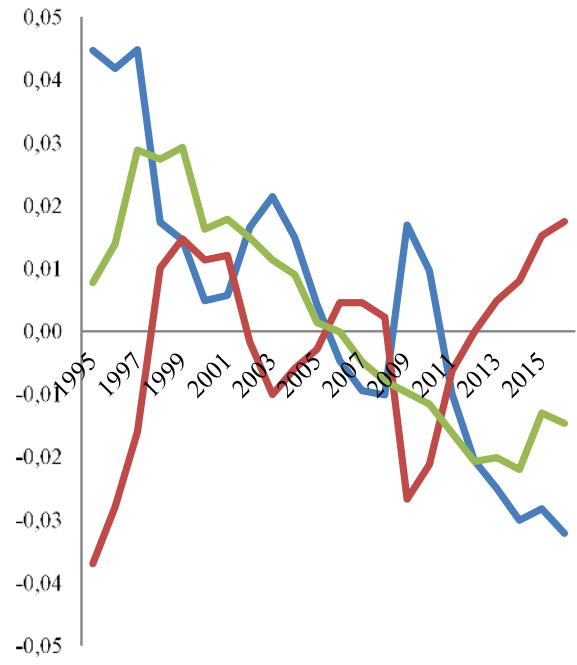

(a) France

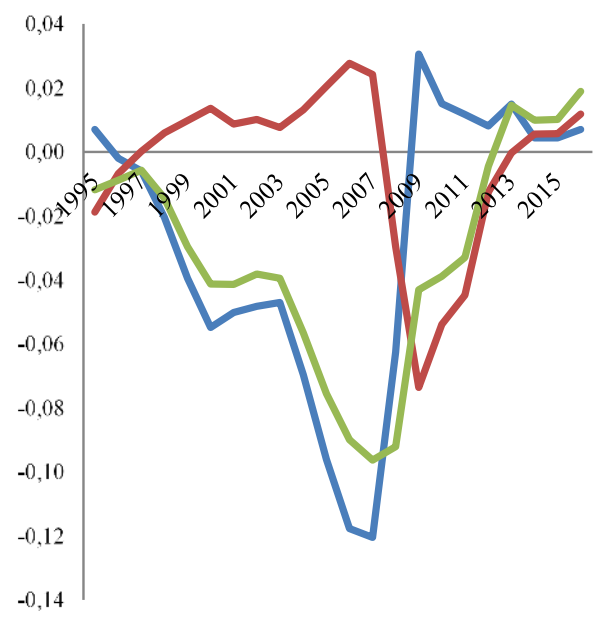

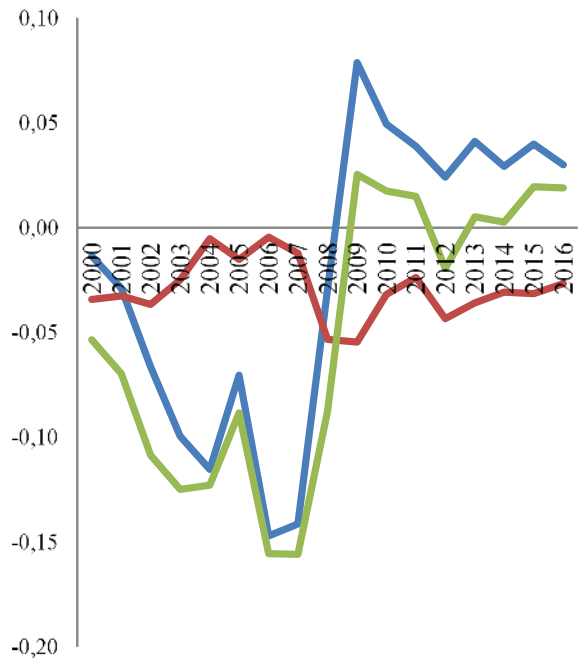

(b) Estonia

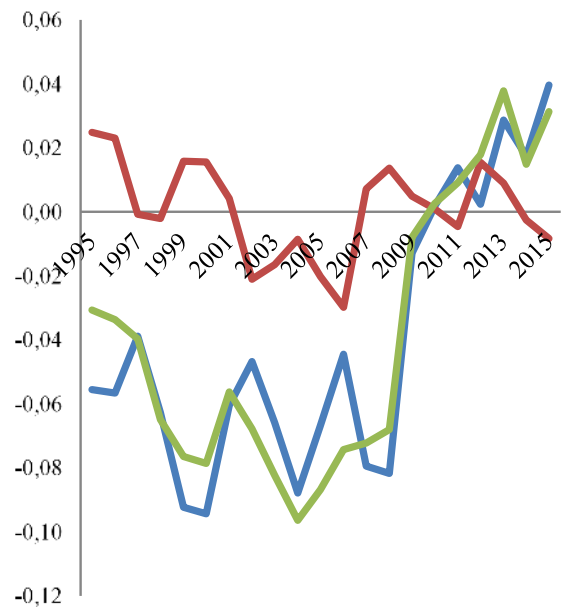

(d) Hungary

( c ) Spain

Note: private balance (blue), government balance (red) and external balance (green).

Source: author's own calculation, based on OECD (2018). 
Figure 1(b) reveals some interesting results for Estonia. The country's private and external balances show a remarkable correlation: both have peaks and troughs in the same dates. Note also the abrupt rise in both balances in the wake of the 2008 subprime crisis. The sign of the balances seems to have changed permanently: both private and external sectors used to be in deficit, and now they are in surplus. This might indicate the existence of acute structural changes in the Estonian economy.

Another strong reaction to the crisis can be seen in Spanish data. All three balances present a turning point from the previous trend: the government sector goes from a surplus to a deficit, and both private and external sectors change from deficits to surpluses. Private and external sectors have changed their usual financial position, from deficits to surpluses, and this look permanent. In fact, finding if Spain's structural changes are similar to those in Estonia could be an interesting research agenda.

In some countries, the correlation between the balances seems to have changed through time ${ }^{6}$. This is the case of Hungary (in Figure 1(d)), whose private and government sectors move in tandem for most of the time, but in more recent years the private sector seems to be moving more closely to the external sector. As in the previous analysis, private and external sectors change their signs, pointing to a structural change that might be happening all over Europe.

\section{A Short-run Growth and Distribution Model of an Open Economy with Government}

Using equation (1) as our starting point, we can define six variables: savings, investment, exports, imports, taxes and government expenditures. But before doing so, let us establish some useful definitions, which are going to be applied in the following discussion. Firstly, we use the conventional decomposition of profit rate (WEISSKOPF, 1979):

$$
r=\frac{\Pi}{p K}=\frac{\Pi}{p Y} \frac{p Y}{Y_{p}} \frac{Y_{p}}{K}=h u \frac{1}{v}
$$

where $\Pi$ is total profits, $K$ is capital stock, $Y_{p}$ is potential output, $h$ is profit share of output, $u$ is rate of capacity utilization, and $v$ is a constant production coefficient.

Prices are determined as a mark-up on labor costs:

$$
p=(1+m) w a,
$$

where $m$ is the mark-up, $w$ is the wage rate, and $a$ denotes the constant labor-output ratio.

\footnotetext{
${ }^{6}$ There are few attempts to statistically access the correlation and causation between sectoral balances. See Barbosa-Filho et al. (2008), Nikiforos et al. (2015) and Kirsten and Morrone (2019).
} 
With those basic relations settled, we can define the variables presented in equation (1). In a classical fashion, it is assumed here that only capitalists save, which gives the following savings function:

$$
\frac{S}{K}=\operatorname{sh} \frac{u}{v}
$$

Investment functions are a controversial point in this literature ${ }^{7}$. The following function, introduced by Marglin and Badhuri (1990), is adopted:

$$
\frac{I}{K}=g=\alpha+\beta u+\gamma h
$$

Now, we turn to government variables. Government expenditures are assumed to be constant. Taxes are a fixed proportion $t$ of output. Normalizing to the capital stock, we perform a simple manipulation that gives us equation (12):

$$
\begin{gathered}
\frac{G}{K}=\bar{G} \\
\frac{T}{K}=t \frac{Y}{K}=t \frac{Y}{Y_{p}} \frac{Y_{p}}{K}=t \frac{u}{v}
\end{gathered}
$$

Exports are exogenous and constant. Imports are a fixed proportion $m$ of output and are defined following the same manipulation applied for taxes.

$$
\begin{array}{r}
\frac{X}{K}=\bar{X} \\
\frac{M}{K}=m \frac{u}{v}
\end{array}
$$

Substituting equations (9) to (14) in (1) and solving for $u$ gives:

$$
u^{*}=\frac{\alpha+\bar{G}+\bar{X}+\gamma h}{\frac{1}{v}(m+t+s h)-\beta}
$$

A standard stability condition, often called "keynesian stability condition", is that savings are more responsive than investment to changes in the capacity utilization rate. In our model, this can be expressed as:

$$
\frac{1}{v}(m+t+s h)>\beta
$$

Substituting $\mathrm{u}^{*}$ in equation (10), we can find the equilibrium accumulation rate:

\footnotetext{
${ }^{7}$ See, for example, the debate between Lavoie $(2016,2017)$ and Skott $(2017)$.
} 


$$
g^{*}=\alpha+\gamma h+\frac{\beta(\alpha+\bar{G}+\bar{X}+\gamma h)}{\frac{1}{v}(m+t+s h)-\beta}
$$

Deriving (15) in relation to the profit share $h$ gives us the effect of a redistribution of income towards profits in the capacity utilization rate. To simplify the notation, we assume $v=1$, which does not change the interpretation of the result:

$$
\frac{\partial u^{*}}{\partial h}=\frac{\gamma(m+t-\beta)-s(\alpha+\bar{G}+\bar{X})}{(m+t+s h-\beta)^{2}}
$$

The economy will have a profit-led demand regime ${ }^{8}$ if expression (18) has a positive sign. Since its denominator is always positive, it is possible to focus on the numerator. The condition for profit-led growth is, thus:

$$
\gamma(m+t-\beta)-s(\alpha+\bar{G}+\bar{X})>0
$$

If the effects of a redistribution of income towards profits on investment are larger than on savings, the demand regime is profit-led. One may wonder why import and tax propensities appear with a positive sign. A look at equation (1) gives the answer: if investment responds more strongly than savings to a redistribution of income towards profits, the negative change in private balance (which can be a decrease in a surplus, an increase in a deficit or a change from surplus to deficit) must be compensated by equivalent changes in the remaining balances (government and external). If savings responds more strongly, the opposite emerges: the private sector has a positive change in its balance that must be compensated by the other sectors (by means of a government deficit and/or a current account surplus, for example). Our point here is that, for an economy to be wage- or profitled, both government and external sector must provide the accounting counterpart.

Now deriving $\mathrm{g}^{*}$ with respect to $h$, the accumulation regime of the economy can be written as:

$$
\frac{\partial g^{*}}{\partial h}=\gamma+\beta \frac{[\gamma(m+t-\beta)-s(\alpha+\bar{G}+\bar{X})]}{(m+t+s h-\beta)^{2}}
$$

The accumulation regime can also be wage-led or profit-led. As before, this depends on the sign of the numerator.

Now it is possible to proceed to a graphical representation of our model. Bringing together equations for investment, exports and government expenditures, the Demand Curve (DC) can be written as:

$$
D C=\alpha+\bar{G}+\bar{X}+\gamma h+\beta u
$$

\footnotetext{
${ }^{8}$ The "demand regime" refers to the determinants of the capacity utilization, whereas the term "accumulation regime" refers to the determinants of the investment (HEIN, 2014). A wage-led (profit-led) demand regime is one in which the capacity utilization raises (falls) after an increase in wages. A wage-led (profit-led) accumulation regime is one in which firms raise (reduce) its investments after an increase in wages.
} 
Combining equations for savings, taxes and imports, the Savings Curve (SC) can be expressed as follows:

$$
S C=(s h+t+m) \frac{u}{v}
$$

The intercept of the curves gives the equilibrium rate of capacity utilization.

In Figures 2, 3 and 4, we present both curves before (solid lines) and after (dashed lines) an increase in profit share. The SC curve rotates upwards, and the DC curve moves upwards. For ease of comparison, the rotation of SC is the same in all graphs, the only difference being in the size of the DC curve shift.

Figure 2 shows the case for a wage-led regime in demand and accumulation. After an increase in profit share, consumption decreases (savings increase), which reduces demand and, therefore, the rate of capital utilization. The negative effect of effective demand upon capital accumulation surpasses the positive effect of an increased profitability, which reduces accumulation.

\section{Figure 2: Effect of an Increase in the Profit Share: the Wage-led Regime}

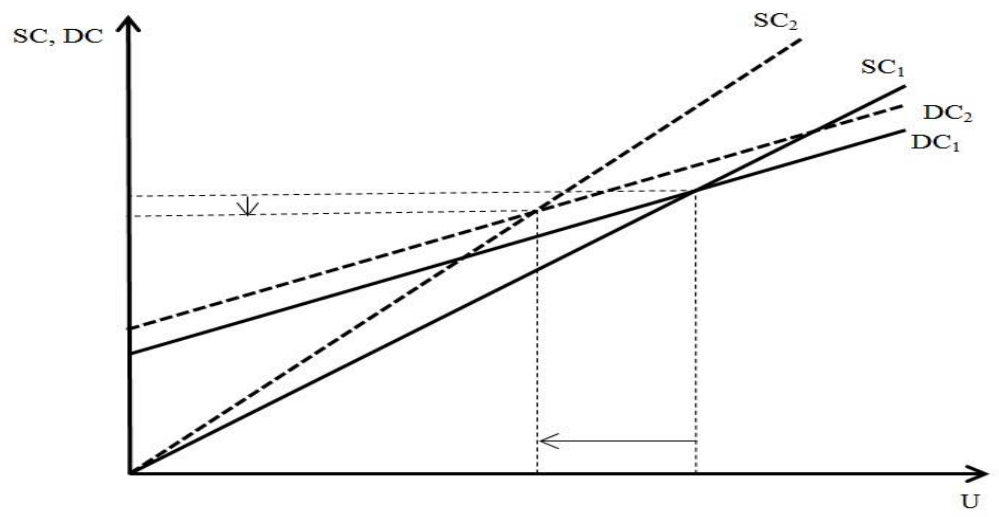

Source: author's own elaboration.

Figure 3 exhibits a mixed (intermediate) case, in which demand is wage-led, but accumulation is profit-led. As before, the redistribution of income towards profits reduces demand, but now the profitability effect on investment is higher than the demand effect, and thus accumulation is profit-led. 
Figure 3: Effect of an Increase in the Profit Share: the Intermediate Regime

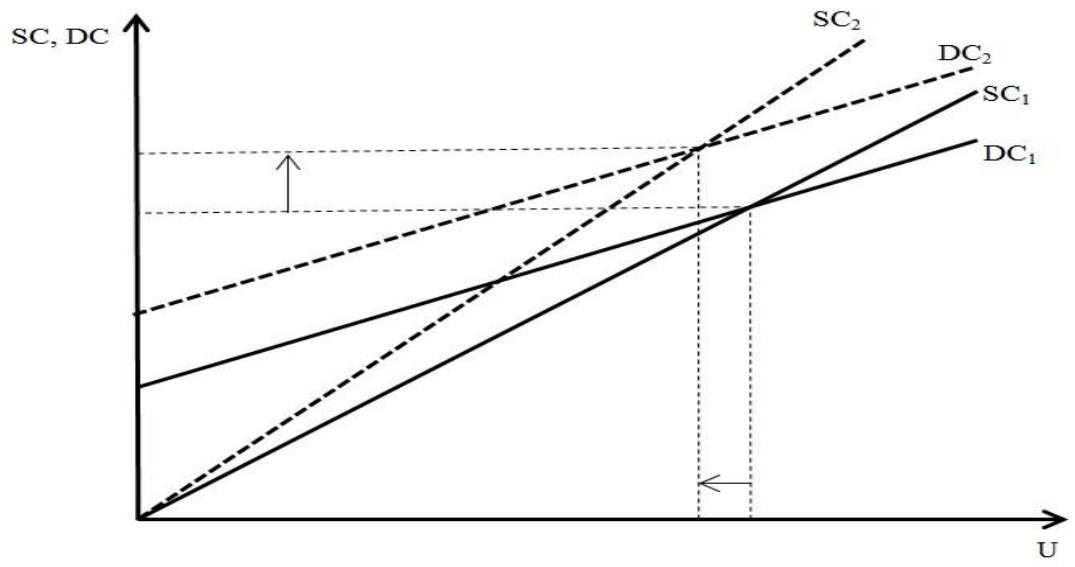

Source: author's own elaboration.

Figure 4 reports a profit-led demand and accumulation regime. An increase in the profit share boosts investment (via the profitability effect), and this increase is higher than the fall in consumption, thus resulting in an increase in the rate of capacity utilization.

Figure 4: Effect of an Increase in the Profit Share: the Profit-led Regime

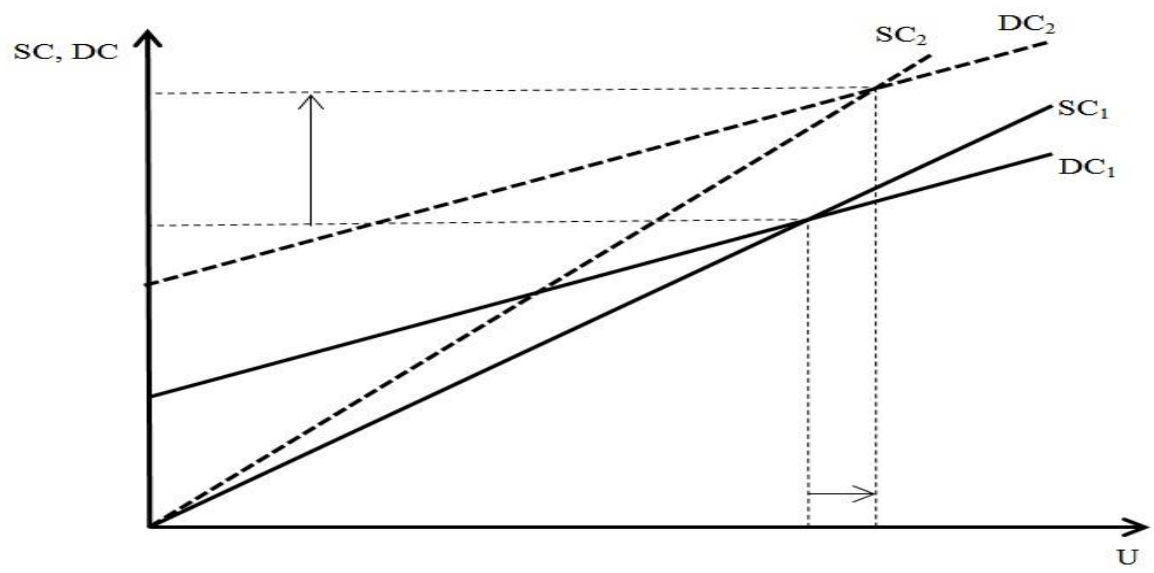

Source: author's own elaboration.

Our simple model can explain a puzzle in the literature. Rearranging (19) for ease of exposition, we find:

$$
(-s \alpha-\gamma \beta)+(\gamma t-s \bar{G})+(\gamma m-s \bar{X}) \lessgtr 0
$$


If the above equation is positive, the economy's demand regime is profit-led ${ }^{9}$. If it is negative, it is wage-led. Notice that the result relies on the values of the parameters $\gamma$ and $s$ (the response of investment on the profit share and the marginal propensity to save, respectively). This is an empirical question but let us assume, for simplicity, that these parameters have similar values ${ }^{10}$. The first brackets are always negative. So, if $\gamma$ and $s$ have similar values, we can assess if an economy is wage-led or profit-led looking at government and external balances.

Let us have a look at Netherlands, a country that has clear figures in its balances. Empirical studies have found mixed results regarding the wage or profit-led nature of this economy. Naastepad (2005) and Naastepad and Storm (2006) have found that it is wageled, whereas Hein and Vogel (2007) found that it is profit-led. Blecker (2011) argues that a small country like Netherlands being wage-led is a result "anomalous theoretically" ( $p$. 232). Now, let us look at the graph together with equation 23 . The government deficit gives a negative sign to the second brackets, and the current account surplus gives another negative sign in the third brackets. So, the equation is overall negative ${ }^{11}$, which gives us a wage-led result. This is not "anomalous theoretically", as Blecker (2011) stated, since our model can explain this: the Netherlands presents a wage-led demand regime because the accounting counterpart given by the government and the external sector favors this result, and not a profit-led regime.

This analysis demonstrates the importance of both government and external sector balances to validate the wage/profit-led regime of an economy. This "validation" might have a higher or smaller magnitude that depends on the size of both balances. Therefore, we recommend that empirical tests of the wage/profit-led regimes must control for government and external sector sizes. For instance, government balance is absent in the empirical analysis of Naastepad (2005) and Naastepad and Storm (2006).

The model delineated above has some correspondence with recent literature on growth and distribution models. Cassetti (2012) presents a model of an open economy with a government sector. However, the author does not stress the relations between the sectoral balances, and there is no discussion about the private sector incurring in deficit or surplus. In the same vein, Caldentey and Vernengo (2017) explore a similar model, which also includes flows of international capital. One drawback is that government balance is not analyzed in detail, nor its connections with results from other sectors. Our model, despite being simpler, gives important insights on those issues.

The model delineated above is the basis upon which we will develop our research agenda. It will be set forth in the next section, together with our final remarks.

\footnotetext{
${ }^{9}$ It is easy to verify that this condition also appears in the derivation of the accumulation regime. We have omitted this from the discussion for space reasons.

${ }^{10}$ In Naastepad and Storm (2006), their empirical estimations of these parameters in fact gives similar values for several countries, including Netherlands.

${ }^{11}$ Remember: if $\gamma$ and $s$ have similar values, which is the result found in Naastepad and Storm (2006). Our assumption is, therefore, supported by the data.
} 


\section{Figure 5: Sectoral Balances: Netherlands}

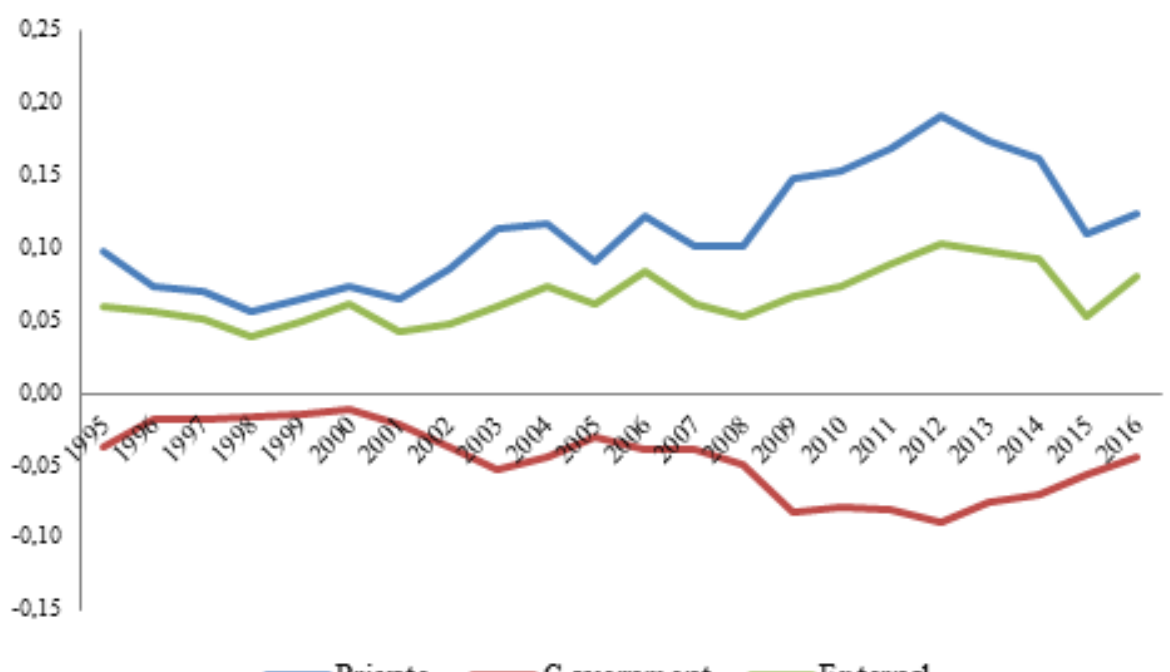

- Private - G overnment External

Source: author's own calculation, based on OECD (2018).

\section{Final Remarks}

The model outlined in this paper is a first step in the introduction of accounting consistency in kaleckian models of growth and distribution. Our contribution was to use the identity given by equation (1) in this growth model. However, further steps should be taken in order to fully introduce stocks and flows in the model.

Table 1 provides the blueprint of our research agenda. Firstly, note that the private sector is highly aggregated. An important step is to separate this sector between households, firms and banks. All those sectors can be further disaggregated: the first between workers and capitalists, the second between producers of consumption and of capital goods, and the last one with the introduction of the shadow banking sector. Those steps can give insights into the role of different propensities to save, of the production structure and effects of finance on a given economy. Moreover, private sector balance can be equilibrated in the aggregate, but with mounting fragility in its components, for example with growing indebtedness in household sector compensated by the banking sector.

The external sector was highly simplified here. We ignored the role of exchange rate, but this is a key variable in determining if an open economy is wage-led or profit-led ${ }^{12}$. Another interesting analysis is to introduce the interest rate and its impacts on capital flows.

${ }^{12}$ On this, see Blecker (2011). 
Further, we should consider the accumulation of foreign reserves and its impacts on the other financial stocks of the system. In order to do so, we must include a Central Bank.

Still considering the external sector, our model can expand the literature on Balance of Payments Constraint. This literature starts with Thirlwall (1979), who presents an analysis of growth sustainability in relation to one of the three sectoral balances delineated in our equation (1). His "law" can be loosely translated to our model as being $\hat{y}=\frac{\bar{X}}{m}$, where $\hat{y}$ is GDP growth. Subsequent developments of this theory, such as Thirlwall and Hussain (1982), can be regarded as an extension of the last row of Table 1, which represents changes in net debt. Capital flows are a counterpart for the net result of (X-M). Moreno-Brid (1998, 2003) and Barbosa-Filho (2001) further extend the model, by analyzing sustainable trade deficits and interest payments on external debt.

Our model can complement the above literature in two ways. The first contribution is theoretical: since the three sectoral balances are connected, to what extent the external balance, and therefore the balance of payments (BP), can be regarded as an independent limit of economic growth? The behavior of private sector and government budget result can affect the constraint given by the BP? And if so, in which ways? The second contribution is empirical, and it is related to a point already mentioned: given the connection of the balances, does the inclusion of government deficit/surplus and private sector balance improve econometric estimations of the BP restraint?

The government can also be studied in more detail. For instance, we ignored (in the theoretical model) the role played by government investment. Another interesting exercise is to introduce several taxes, as was done by Mott and Slatiery (1994). The way government deficits are financed are also a fundamental point of future research, as well as the analysis of fiscal policy rules ${ }^{13}$.

To be consistent, the models should add the influence of stocks on flows. An important starting point of reference is Leite (2015), who uses equation (1) and introduces the influence of private wealth accumulation in its behavioral equations. An extension of his model, integrating it with Kaleckian hypothesis, might lead to interesting results. Another work that can be used is Dafermos (2017), who develop a model around the notion that the private sector adjusts its expenditures to maintain a target debt to income ratio. The introduction of this ratio is an interesting avenue of research.

Another important point is that imbalances between sectors accumulate in stocks, but this accumulation cannot last forever. A related question is the interest that must be paid over accumulated debts. On this regard, the analysis of Moreno-Brid (1998, 2003), Barbosa-Filho (2001) and Blecker (2013) in the context of balance of payments models and of Galbraith (2011) for the government balance must be included as an extension of our basic model.

The empirical connection between the three sectoral balances is also an important avenue of research. Very few attempts were made in the determination of causality between the results of one sector to another. Barbosa-Filho et al. (2008) study the case of the United

${ }^{13}$ On fiscal policy rules in SFC models, see Le Heron (2012) and Kappes and Milan (2017). 
States and concludes that "households net borrowing Granger causes foreign net borrowing" (p. 631). Kirsten and Morrone (2019) analyze the Brazilian economy and conclude that both private sector and external sector balances Granger-cause government balance. More analysis in the spirit of these two papers would doubtless improve our understanding of the relations among macroeconomic sectors and their influence on the overall economic performance ${ }^{14}$.

The role of financial crisis in growth and distribution is another question of research. Crisis such as the 2008 subprime crisis have permanent effects on economic growth, and those effects are likely to feedback on income distribution and then again to growth. The effects of government intervention, such as Quantitative Easing, and the consequent changes in financial portfolios of banks and monetary authorities is another interesting point.

Finally, the interaction between financial balances composition and wage- or profitled results must be investigated. Blecker (2013) shows that an economy with the same parameters can be profit-led or wage-led depending on the origin of the distributive shock (it might come through changes in wage rate or in mark-up rate). Naastepad (2005) shows that, depending on the behavior of the productivity growth, a wage-led economy behaves like a profit-led economy, or vice-versa. It might be that an economy with the same parameters can be profit-led or wage-led depending on the financial composition of its sectors.

All the above points are in the theoretical front. The empirical side also presents many challenges. First, our database must be increased, both in the number of countries and in years in the sample. The private sector must be disaggregated in households, firms and banks when date is available. Statistical analysis of correlation and causation must be taken, as well as a study of the determinants of financial balances behavior.

We hope to have provided a flexible framework that can be used to shed light in the questions raised in the introduction. The empirical power of the financial balances approach, that proved itself during the subprime crisis, together with the relevant points raised by Kaleckian models, is a promising integration that should be used to develop more robust theoretical models, empirical oriented analysis and policy prescriptions in order to fight slow growth, inequality and economic instability.

\footnotetext{
14 The database constructed by Schularick (2013), compiling data on public and private debt from 1870 to 2010 for 17 advanced economies, is of great value for such an analysis.
} 


\section{References}

BADHURI, A; MARGLIN, S. Unemployment and Real Wage: the Economic Basis for Contesting Political Ideologies. Cambridge Journal of Economics, v. 14, n. 4, 375-93, 1990. DOI: https://doi.org/10.1093/oxfordjournals.cje.a035141

BARBOSA-FILHO, N. H. The balance-of-payments constraint: from balanced trade to sustainable debt. PSL Quarterly Review, v. 54, n. 219, 2001.

BARBOSA-FILHO, N. H.; RADA, C.; TAYLOR, L; ZAMPARELLI, L. Cycles and trends in US net borrowing flows. Journal of Post Keynesian Economics, v. 30, n. 4, p. 623-648, 2008. DOI: https://doi.org/ 10.2753/PKE0160-3477300407

BEZEMER, D. J. Understanding financial crisis through accounting models. Accounting, Organizations and Society, Amsterdan, v. 35, n. 7, p. 676-688, 2010. DOI:

https://doi.org/10.1016/j.aos.2010.07.002

BIBOW, J. Of Unsustainable Processes and the US Dollar. In.: Papadimitriou, D.; Zezza, G. Contributions to Stock-Flow Modeling: Essays in Honor of Wynne Godley. New York: Palgrave Macmillan, p. 321-348, 2012.

BLECKER, Robert. A. Open economy models of distribution and growth. In.: HEIN, E; STOCKHAMMER, E.A Modern Guide to Keynesian Macroeconomics and Economic Policies. Cheltenham, UK: Edward Elgar, p. 215-39, 2011.

BLECKER, Robert. A. Long-Run Growth in Open Economies: Export-Led Cumulative Causation or a Balance-of-Payments Constraint? In.: HARCOURT, G.; KRIESLER, P. The Oxford Handbook of Post- Keynesian Economics. Oxford University Press, p. 2013.

BRAINDARD, W; TOBIN, J. Pitfalls in financial model building. The American Economic Review, v. 58, n. 2, p. 99-122, 1968.

BRECHT, M.; TOBER, S.; VAN TREECK, T.; TRUGER, A. Squaring the Circle in Euro Land? Some Remarks on the Stability Programmes 2010-13. In.: Papadimitriou, D.; Zezza, G. Contributions to Stock-Flow Modeling: Essays in Honor of Wynne Godley. New York: Palgrave Macmillan, p. 349-376, 2012.

BRUNNERMEIER, M. K.; EISENBACH, T. M.; SANNIKOV, Y. Macroeconomics with financial frictions: A survey. National Bureau of Economic Research, Working paper n. 18102, 2012.

CALDENTEY, E. P.; VERNENGO, M. Toward an Understanding of Crises Episodes in Latin America: A Post-Keynesian Approach. Review of Keynesian Economics, v. 3, n. 2, p. 158-180, 2015. DOI: https://doi.org/10.4337/roke.2015.02.02 
CALDENTEY, E. P; VERNENGO, M. Wage-led, debt-led growth in an open economy. Review of Keynesian Economics, v. 5, n. 3, p. 307-335, 2017. DOI:

https://doi.org/10.4337/roke.2017.03.02

CASSETTI, M. Macroeconomic outcomes of changing social bargains. The feasibility of a wage-led open economy reconsidered. Metroeconomica, v. 63, n. 1, p. 64-91, 2012. DOI: https://doi.org/10.1111/j.1467-999X.2011.04129.x

CAVERZASI, E; GODIN, A. Post-Keynesian stock-flow-consistent modelling: a survey. Cambridge Journal of Economics, Cambridge, v. 39, n. 1, p. 157-187, 2015. DOI: https://doi.org/10.1093/cje/beu021

DAFERMOS, Y. Debt cycles, instability and fiscal rules: a Godley-Minsky synthesis. Cambridge Journal of Economics, v. 42, n. 5, p. 1277-1313, 2017. DOI: https://doi.org/10.1093/cje/bex046

EATWELL, J; TAYLOR, L. The American stock-flow trap. Challenge, Oxford, v. 42, n. 5, p. 34-49, 1999.

EGGERTSSON, G. B.; N. R. MEHROTRA; L. H. SUMMERS. Secular stagnation in the open economy. The American Economic Review, v. 106, n. 5, p. 503-07, 2016.

GALBRAITH, J. K. Is the Federal Debt Unsustainable? Levy Economics Institute Policy Note, n. 2011/2, 2011.

GODLEY, W. Money, finance and national income determination: an integrated approach. New York: Levy Economics Institute of Bard College Working Paper, n. $167,1996$.

GODLEY, W. Seven Unsustainable Processes. New York: Levy Economics Institute of Bard College, Special Report ,1999.

GODLEY, Wynne; CRIPPS, Francis. Macroeconomics. Oxford: Oxford University Press, 1983.

GODLEY, W.; MCCARTHY, G. Fiscal policy will matter. Challenge, Oxford, v. 41, n. 1, p. 38-54, 1998.

GODLEY, W; SHAIKH, A. An important inconsistency at the heart of the standard macroeconomic model. Journal of Post Keynesian Economics, Oxford, v. 24, n. 3, p. 423-441, 2002. DOI: https://doi.org/10.1080/01603477.2002.11490334

GODLEY, W; IZURIETA, A. Balances, Imbalances and Fiscal Targets: a new Cambridge view. 2004. Disposable at $<<$ https://www.soas.ac.uk/cdpr/expertise/worldmodel/file45187.pdf >> Access in September $10,2018$. 
GODLEY, W; LAVOIE, M. Monetary Economics: an integrated approach to credit, money, income, production and wealth. New York: Palgrave Macmillan, 2007.

GODLEY, W.; PAPADIMITRIOU, D.; HANNSGEN, G.; ZEZZA, G. The US Economy Is There a Way Out of the Woods? Strategic Analysis, Jerome Levy Economics Institute, Bard College, 2007.

GORDON, Robert. J. The Rise and Fall of American Growth: the U.S. standard of living since the civil war. Princeton: Princeton University Press, 2016.

HEIN, Eckhard. Distribution and Growth After Keynes: A post-keynesian guide. Northampton: Edward Elgar Publishing, 2014.

HEIN, E.; VOGEL, L. Distribution and growth reconsidered: empirical results for six OECD countries. Cambridge Journal of Economics, v. 32, n. 3, p. 479-511, 2007. DOI: https://doi.org/10.1093/cje/bem047

KAPPES, S. A.; MILAN, M. Fiscal policy rules in a stock-flow consistent model. Brazilian Keynesian Review, v. 3, n. 2, p. 32-55, 2017.

KIRSTEN, M. B.; MORRONE, H. Choque externos e desequilíbrios financeiros: uma interpretação sobre a crise brasileira. Brazilian Keynesian Review, v. 5, n. 1, p. 43-68, 2019.

KREGEL, J. Debtors' Crisis or Creditors' Crisis? Who Pays for the European Sovereign and Subprime Mortgage Losses. New York: Levy Economics Institute of Bard College Public Policy Brief, n. 121, 2011.

LAVOIE, M. Financialisation issues in a Post-Keynesian stock-flow consistent model. Intervention - European Journal of Economics and Economic Policies, Cheltenham, v. 5, n. 2, p. 335-361, 2008.

LAVOIE, M. Convergence Towards the Normal Rate of Capacity Utilization in NeoKaleckian Models: The Role of Non-Capacity Creating Autonomous Expenditures.

Metroeconomica, v. 67, n. 1, p. 172-201, 2016. DOI:

https://doi.org/10.1111/meca.12109

LAVOIE, M. Prototypes, reality and the growth rate of autonomous consumption expenditures: a rejoinder. Metroeconomica, v. 68, n. 1, p. 194-199, 2017. DOI: https://doi.org/10.1111/meca.12152

LE HERON, E. A Debate with Wynne Godley on the Neutrality of Fiscal Policy. In.: Papadimitriou, D.; Zezza, G. Contributions to Stock-Flow Modeling: Essays in Honor of Wynne Godley. New York: Palgrave Macmillan, p. 266-299, 2012.

LEITE, F. Taking Godley's Ratios Seriously. Metroeconomica, v. 66, n. 3, p. 508-533, 2015. DOI: https://doi.org/10.1111/meca.12077 
MATA, T. Godley Moves in Mysterious Ways: The Craft of Economic Judgment in Postwar Britain. In.: Papadimitriou, D.; Zezza, G. Contributions in Stock-flow Modeling. New York: Palgrave Macmillan UK, p. 12-35, 2012.

MARGLIN, S.; BHADURI, A. 1990. Profit Squeeze and Keynesian Theory, In.: Marglin S.; Schor, J. The Golden Age of Capitalism: Reinterpreting the Postwar Experience. Oxford: Oxford University Press.

MORENO-BRID, J. C. On capital flows and the balance-of-payments-constrained growth model. Journal of Post Keynesian Economics, v. 21, n. 2, p. 283-298, 1998. DOI: https://doi.org/10.1080/01603477.1998.11490194

MORENO-BRID, J. C. Capital flows, interest payments and the balance-of-payments constrained growth model: A theoretical and empirical analysis. Metroeconomica, v. 54, n. 2-3, p. 346-365, 2003. DOI: https://doi.org/10.1111/1467-999X.00170

MOTT, T; SLATIERY, E. Tax incidence and macroeconomic effects in a Kaleckian model when profits finance affects investment and prices may respond to taxes. Journal of Post Keynesian Economics, v. 16, n. 3, p. 391-410, 1994. DOI: https://doi.org/10.1080/01603477.1994.11489992

NAASTEPAD, C. W. M. Technology, demand and distribution: a cumulative growth model with an application to the Dutch productivity growth slowdown. Cambridge Journal of Economics, v. 30, n. 3, p. 403-434, 2005. DOI: https://doi.org/10.1093/cje/bei063

NAASTEPAD, C. W. M.; STORM, S. OECD demand regimes (1960-2000). Journal of Post Keynesian Economics, v. 29, n. 2, p. 211-246, 2006. DOI: https://doi.org/10.2753/PKE0160-3477290203

NIKIFOROS, M.; ZEZZA, G. Stock-flow Consistent Macroeconomic Models: A Survey. Journal of Economic Surveys, v. 31, n. 5, p. 1204-1239, 2017. DOI:

https://doi.org/10.1111/joes.12221

NIKIFOROS, M.; CARVALHO, L.; SCHODER, C. "Twin deficits" in Greece: in search of causality. Journal of Post Keynesian Economics, v. 38, n. 2, p. 302-330, 2015. DOI: https://doi.org/10.1080/01603477.2015.1065675

OCAMPO, Jose Antonio; Codrina Rada; Lance Taylor. Growth and policy in developing countries: a structuralist approach. New York: Columbia University Press, 2009. $178 \mathrm{p}$.

ORGANIZATION FOR ECONOMIC CO-OPERATION AND DEVELOPMENT (OECD). [internet]. 2018. OECD Stat data. [access in August 2018] Available in: <https://data.oecd.org/> 
PIKETTY, Thomas. Capital in the 21st Century. Cambridge: Harvard University Press, 2014.

REZENDE, F. Financial Fragility, Instability and the Brazilian Crisis: a KeynesMinsky-Godley approach. Minds. Multidisciplinary Institute for Development and Strategies: Discussion paper, v. 1, 2016.

RICHTERS, O; SIEMONEIT, A. Consistency and stability analysis of models of a monetary growth imperative. Ecological Economics, v. 136, p. 114-125, 2017. DOI: https://doi.org/10.1016/j.ecolecon.2017.01.017

SANTOS, C. H. Notas sobre a crescente (e peculiar) fragilidade financeira do capitalismo norte-americano. Economia e Sociedade, Campinas, v. 13, n. 2, p. 23-49, 2004.

SANTOS, J. F. C. Ensaios sobre crescimento, restrição ao balanço de pagamentos e distribuição de renda em abordagem Stock-Flow Consistent (SFC), 2017. 188 p. Tese (Doutorado) - Universidade Federal de Uberlândia, Instituto de Economia, Uberlândia, MG.

SANTOS, J. F. C.; OREIRO, J. L. C. The impossible Quartet in a Demand Led GrowthSupermultiplier Model for a Small Open Economy. In: XII Encontro Internacional da AKB, 2019, Campinas.

SCHULARICK, M. Public and private debt: the historical record (1870-2010). German Economic Review, v. 15, n. 1, p. 191-207, 2013. DOI: https://doi.org/10.1111/geer.12031

SKOTT, P. Autonomous demand and the Harrodian criticisms of the Kaleckian model. Metroeconomica, v. 68, n. 1, p. 185-193, 2017. DOI:

https://doi.org/10.1111/meca.12150

SUMMERS, L. H. US economic prospects: Secular stagnation, hysteresis, and the zero lower bound. Business Economics, v. 49, n. 2, p. 65-73, 2014. DOI: https://doi.org/10.1057/be.2014.13

TAYLOR, L. Exchange rate indeterminacy in portfólio balance, Mundell-Fleming and uncovered interest rate parity models. Cambridge Journal of Economics, Cambridge, v. 28, n. 2, p. 205-227, 2004. DOI: https://doi.org/10.1093/cje/28.2.205

THIRLWALL, A. P. The balance of payments constraint as an explanation of international growth rate differences. BNL Quarterly Review, v. 32, n. 128, p. 45-53, 1979.

THIRLWALL, A. P.; HUSSAIN, M. N. The balance of payments constraint, capital flows and growth rate differences between developing countries. Oxford Economic Papers, v. 34, n. 3, p. 498-510, 1982. DOI: https://doi.org/10.1093/oxfordjournals.oep.a041565 
VERA, L. Reassessing fiscal policy: perspectives from developing countries.

Development and Change, v. 40, n. 4, p. 611-643, 2009. DOI:

https://doi.org/10.1111/j.1467-7660.2009.01565.x

WEISSKOPF, T. E. Marxian crisis theory and the rate of profit in the Postwar U.S. economy. Cambridge Journal of Economics, v. 3, n. 4, p. 341-378, 1979. DOI: https://doi.org/10.1093/oxfordjournals.cje.a035429

ZEZZA, G. Fiscal policy and the economics of financial balances. European Journal of Economics and Economic Policies: Intervention, v. 6, n. 2, p. 289-310, 2009. DOI: https://doi.org/10.4337/ejeep.2009.02.11 


\section{Appendix}

\section{Table A1: Data sources and codes}

\begin{tabular}{|c|c|c|}
\hline Symbol & $\begin{array}{l}\text { Variable } \\
\end{array}$ & Description \\
\hline$G D P_{m p}$ & $\begin{array}{l}\text { Gross domestic product at market } \\
\text { prices }\end{array}$ & $\begin{array}{l}\text { Gross domestic product (output approach) } \\
\text {-B1_GA }\end{array}$ \\
\hline$N P I^{*}$ & $\begin{array}{l}\text { Net private income of the external } \\
\text { sector }\end{array}$ & $\begin{array}{l}\text { Net primary incomes from the rest of the } \\
\text { world - D1_D4NFRS2 }\end{array}$ \\
\hline$T$ & Total taxes & Total tax receipts - D2D5D91 \\
\hline$C$ & Private final consumption & $\begin{array}{l}\text { Final Consumption Expenditure of } \\
\text { Households and Non-profit institutions } \\
\text { serving households - P31S14_S15 }\end{array}$ \\
\hline$I_{g}$ & Government gross capital formation & $\begin{array}{l}\text { Gross capital formation and acq. less } \\
\text { disposals of non-fin. non-prod.assets by the } \\
\text { government - P5_K2CG }\end{array}$ \\
\hline$I_{p}$ & Private gross capital formation & $\begin{array}{l}\text { Derived by subtracting P5_K2CG from P5 } \\
\text { (Gross capital formation) }\end{array}$ \\
\hline$G$ & Government final expenditures & $\begin{array}{l}\text { Final consumption expenditure of general } \\
\text { government - P3S } 13\end{array}$ \\
\hline$N X$ & Net exports & $\begin{array}{l}\text { P6 minus P7 - "Exports of goods and } \\
\text { services" minus "Imports of goods and } \\
\text { services". }\end{array}$ \\
\hline$N T G_{p s}$ & $\begin{array}{l}\text { Net transfers of the government to the } \\
\text { private sector }\end{array}$ & No data available \\
\hline$N T G_{e x}$ & $\begin{array}{l}\text { Net transfers of the government to the } \\
\text { external sector }\end{array}$ & $\begin{array}{l}\text { Included in "Net current transfers from the } \\
\text { rest of the world"-D5_D7NFRS2 }\end{array}$ \\
\hline$N T P_{e x}$ & $\begin{array}{l}\text { Net transfers of the private sector to } \\
\text { the external sector }\end{array}$ & $\begin{array}{l}\text { Included in "Net current transfers from the } \\
\text { rest of the world"- D5_D7NFRS2 }\end{array}$ \\
\hline
\end{tabular}

Note: all the data came from OECD (2018), extracted in August 2018. 